УДК 37.018.4:004.032.6

Аврамчук Антон Миколайович

аспірант

Інститут інформаційних технологій і засобів навчання НАПН України, м. Київ, Україна

avramchuk92@gmail.com

\title{
ОГЛЯД ДОДАТКІВ СИСТЕМИ МООDLЕ ДЛЯ ПРОЕКТУВАННЯ МУЛЬТИМЕДІЙНИХ ЕЛЕКТРОННИХ ОСВІТНІХ РЕСУРСІВ 3 МОВНИХ ДИСЦИПЛІн
}

\begin{abstract}
Анотація. На сьогодні проблема проектування мультимедійних електронних освітніх pecyрсів 3 мовних дисциплін в системі Moodle $\epsilon$ дуже актуальною. Ця система має багато різних, потужних ресурсів, додатків, щоб полегшити процес навчання студентів 3 мовних дисциплін. У цій статті наведено огляд і порівняльний аналіз п'ятьох додатків системи Moodle для проектування мультимедійних електронних освітніх ресурсів 3 мовних дисциплін. Розглянуто їх основні характеристики і функціональні можливості з метою вибору найкращого задля вивчення мовних дисциплін у системі Moodle. Додатки порівнюються групою експертів за критеріями: ефективність, функціональність і простота використання. Для порівняльного аналізу додатків застосовується метод аналізу ієрархій.
\end{abstract}

Ключові слова: електронні освітні ресурси; проектування мультимедійних електронних освітніх ресурсів; ефективність; функціональність; простота використання; Moodle; Rich Media; PoodLL; Listening Landscape; YouTube Anywhere; NanoGong.

\section{1. ВСТУП}

Постановка проблеми. В останні роки інформаційно-комунікаційні технології (ІКТ) бурхливо розвиваються й упроваджуються в освітню галузь. Створюється i використовується багато різних електронних освітніх ресурсів, систем дистанційного навчання, електронних бібліотек та ін. задля підтримки і полегшення процесу навчання.

Важливе місце займає проблема проектування мультимедійних електронних освітніх ресурсів у системі Moodle, зокрема з мовних дисциплін.

Проектування мультимедійних ЕОР - це діяльність зі структурування i зовнішнього оформлення навчального матеріалу шляхом його обгрунтованого подання мультимедійними даними на екрані в естетичному керованому вигляді, 3 метою створення максимально ефективних умов для реалізації навчання з використанням IКТ $[3$, c. 7].

Мультимедійні EOP у системі Moodle у процесі викладання мовних дисциплін підвищують ефективність формування мовних і мовленнєвих компетентностей у студентів завдяки впливу графічних i вербальних стимулів, що сприяють конструюванню у них зорових і слухових видів сприйняття.

Проектуючи i використовуючи мультимедійні ЕОР, викладач може подати інформацію в абсолютно новій і ефективній формі, зробити ії більш повною, цікавою та наближеною до тематики, що вивчається, може значно урізноманітнити інформацію і на базі звичайних вправ зробити подання інформації більш легкою, а подання матеріалу більш цікавим.

Аналіз останніх досліджень і публікацій. Проблема проектування, створювання та використання електронних освітніх ресурсів, зокрема мультимедійних, 3 мовних дисциплін активно досліджується науковцями. Вона розглядалася у працях В.Ю. Бикова, А. М. Гуржія, С. М. Денисенко, О. Е. Коневщинської, Т. І. Коваль, В. Є. Козлова, В. В. Лапінського, О. М. Сальникова, О. А. Щербини та ін. 
Проектування, створювання та використання мультимедійних електронних освітніх ресурсів 3 мовних дисциплін присвячені роботи дослідників М. М. Боремчука, С. П. Кожушко, В.В.Коржа, П. І. Сердюкова, Л. І. Скалій, О.Б. Тарнопольского, П. Ф. Шпірко. Серед зарубіжних дослідників, які досліджували проблему проектування i використання мультимедійних електронних освітніх ресурсів 3 мовних дисциплін, зокрема в системі Moodle, слід виокремити таких: M. D. Bush, Klaus Brandl, G. A. Cziko, B. Godwin-Jones, Justin Hunt, Claudia Warth-Sontheimer та ін.

Мета статті. Зробити огляд і дати порівняльний аналіз додатків системи Moodle для проектування мультимедійних електронних освітніх ресурсів 3 мовних дисциплін.

\section{2. РЕЗУЛЬТАТИ ДОСЛІДЖЕННЯ}

Додаток Rich Media для системи Moodle. Додаток Rich Media [1] - це перший відомий нам безкоштовний засіб створення відеолекцій, який попри це використовується не як ресурс, а як діяльність Moodle, бо надає викладачеві звіти про те, хто, коли і скільки раз слухав відеолекцію.

Під відеолекцією ми розуміємо мультимедійну оффлайн презентацію, де на основному екрані, зазвичай, відображається ілюстративний матеріал лекції - слайди, що містять текст і графіку, у кутку екрана можна бачити відео із зображенням лектора або інші відеоматеріали, а внизу розміщені засоби навігації, які дозволяють зупиняти і

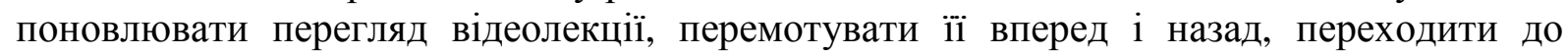
бажаного розділу тощо.

Rich Media - це засіб створення і відображення мультимедійних презентацій (відео + слайди синхронізовано). Він був розроблений французькою компанією Symetrix у рамках проекту з електронного навчання для CHEMI (Centre des Hautes Etudes du Ministère de l'Intérieur français).

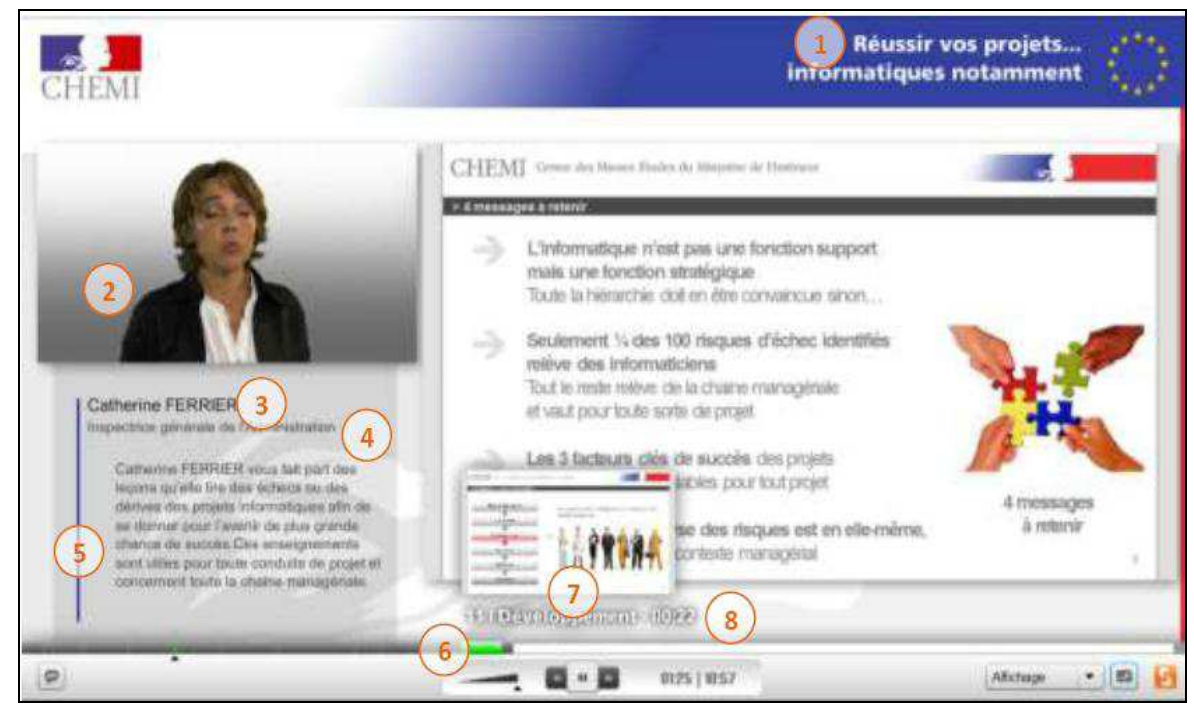

Puс. 1. Вікно додатку Rich Media

Для створення відеолекції треба завантажити zір-архів зі слайдами (графічні зображення у форматі jpg, png, та інші сумісні з браузером) і файл відео з виступом лектора, а потім здійснити їх синхронізацію, відмічаючи кліком мишки потрібні слайди 
в процесі перегляду відео. У результаті створюється файл синхронізації, що містить інформацію про те, на якій секунді перегляду відео показуватиметься той чи інший слайд.

Щоб записати відео лектора, можна скористатися будь-якою програмою для запису відео з веб-камери. Цей відеозапис можна робити і під час синхронізації. Правда, спочатку доведеться завантажити на сайт яке завгодно відео, а потім замінити його справжнім, щойно записаним.

За термінологією Moodle, відеолекції Rich Media (рис. 1) є діяльністю, а не ресурсом, бо надають викладачеві звіти про те, хто, коли і скільки разів переглядав відеолекцію.

Створену відеолекцію можна переглядати і поза Moodle, бо додаток Rich Media дозволяє експортувати іï в пакет SCORM [4].

Перед початком роботи 3 Rich Media треба звернути увагу на плеєри, за допомогою яких Rich Media буде програватися у браузері. Додаток підтримує два плеєри: Adobe Flash i HTML5. У табл. 1 ,представлені основні характеристики цих плеєрів.

Таблиия 1

\section{Характеристики плесрів}

\begin{tabular}{|c|c|c|}
\hline & $\begin{array}{c}\text { Adobe Flash } \\
\text { (повнофункціональна версія) }\end{array}$ & $\begin{array}{c}\text { HTML } 5 \\
\text { (полегшена версія) }\end{array}$ \\
\hline Екран відкривається & У тому ж вікні & У новій вкладці \\
\hline Підтримувані формати відео & $\begin{array}{l}\text { MP4: Chrome, Firefox, IE } \\
\text { FLV: Chrome, Firefox, IE }\end{array}$ & $\begin{array}{c}\text { MP4: Safari, Chrome, IE9 } \\
\text { OGG: Chrome, Firefox, Opera } \\
\text { WebM: Chrome, Firefox, Opera }\end{array}$ \\
\hline $\begin{array}{l}\text { Підтримувані формати } \\
\text { слайдів }\end{array}$ & $\begin{array}{l}\text { JPG, PNG та інші формати, } \\
\text { сумісні з браузером }\end{array}$ & $\begin{array}{l}\text { JPG, PNG та інші формати, } \\
\text { сумісні з браузером }\end{array}$ \\
\hline Відтворення відео & За допомогою Flash-плагіна & За допомогою браузера \\
\hline Режим відображення & «Мозаїка», «Слайд», «Відео» & Спрощена «Мозаїка» \\
\hline Повноекранний режим & Так & $\begin{array}{c}\text { Тільки Safari, Firefox (правий клік } \\
\text { на відео, і вибір повноекранного } \\
\text { режиму) }\end{array}$ \\
\hline $\begin{array}{l}\text { Підтримка мобільних } \\
\text { пристроїв }\end{array}$ & $\begin{array}{c}\text { Там, де встановлений Flash- } \\
\text { плеєр }\end{array}$ & iPhone, iPad, Blackberry \\
\hline
\end{tabular}

Додаток PoodLL для системи Moodle. PoodLL - це серія додатків для системи Moodle [2]. PoodLL має такі основні функції: аудіо і відеозаписи, дошки для малювання. Цей додаток часто використовується задля вивчення іноземних мов у класах, але є багато людей, що використовують його по-різному.

PoodLL як i Moodle $\epsilon$ безкоштовним і відкритим вихідним кодом. Тобто є доступ до вихідного коду, якщо ви хочете змінити або розширити його.

PoodLL складається 3 дев'яти додатків (рис. 1, таблиця. 2). Основним додатком $є$ PoodLL Filter, без наявності котрого інші додатки працювати не будуть. 


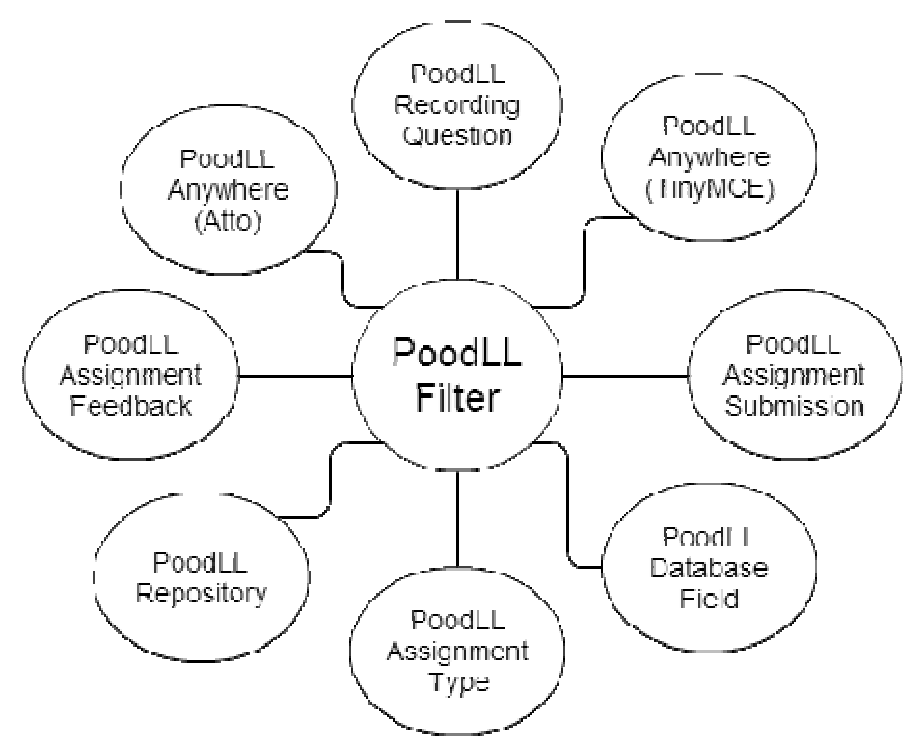

Puc. 2. Додатки PoodLL

Табличя 2

\section{Додатки PoodLL}

\begin{tabular}{|c|c|c|}
\hline Назва додатка & Тип додатка & Опис \\
\hline PoodLL Filter & Filter & $\begin{array}{l}\text { Додаток, у якому розміщені всі загальні функції і } \\
\text { конфігурації. Також його можна використовувати для } \\
\text { обробки мультимедія. } \\
\text { PoodLL Filter є головною складовою для використання всіх } \\
\text { інших додатків PoodLL }\end{array}$ \\
\hline $\begin{array}{l}\text { PoodLL Recording } \\
\text { Question }\end{array}$ & Question Type & $\begin{array}{l}\text { Дозволяє студентам записувати аудіо й малювати відповіді } \\
\text { на запитання викладача }\end{array}$ \\
\hline $\begin{array}{l}\text { PoodLL } \\
\text { Assignment } \\
\text { Submission }\end{array}$ & $\begin{array}{c}\text { Assignment } \\
\text { Submission Type }\end{array}$ & $\begin{array}{l}\text { Дозволяє записувати аудіо і малювати на дошці в } \\
\text { завданнях. Призначений для Moodle } 2.3 \text { і вище }\end{array}$ \\
\hline $\begin{array}{l}\text { PoodLL } \\
\text { Assignment Type }\end{array}$ & $\begin{array}{l}\text { Assignment } \\
\text { Type(2.2) }\end{array}$ & $\begin{array}{l}\text { Дозволяє записувати аудіо i малювати на дошці в } \\
\text { завданнях. Призначений для Moodle } 2.2 \text { i нижче }\end{array}$ \\
\hline $\begin{array}{l}\text { PoodLL } \\
\text { Assignment } \\
\text { Feedback }\end{array}$ & $\begin{array}{l}\text { Assignment } \\
\text { Feedback Type }\end{array}$ & $\begin{array}{l}\text { Дозволяє викладачам записувати аудіо і малювати на } \\
\text { дошці у виконаних завданнях для зворотного зв'язку зі } \\
\text { студентами }\end{array}$ \\
\hline $\begin{array}{l}\text { PoodLL } \\
\text { Repository }\end{array}$ & Repository & $\begin{array}{l}\text { Дозволяє зберігати аудіо записи і малюнки за допомогою } \\
\text { сховищ Moodle }\end{array}$ \\
\hline $\begin{array}{l}\text { PoodLL Database } \\
\text { Field }\end{array}$ & Database Field & $\begin{array}{l}\text { Дозволяє записувати аудіо і малювати в межах бази даних } \\
\text { Moodle }\end{array}$ \\
\hline
\end{tabular}




\begin{tabular}{|c|c|l|}
\hline $\begin{array}{c}\text { PoodLL Anywhere } \\
\text { (TinyMCE) }\end{array}$ & $\begin{array}{c}\text { TinyMCE Editor } \\
\text { Plugin }\end{array}$ & $\begin{array}{l}\text { Забезпечує іконку для кожного аудіозапису і малюнка на } \\
\text { дошці в ТіпуМСE html еditor. Студенти і вчителі можуть } \\
\text { ефективно використовувати РоодLL в будь-якому місці }\end{array}$ \\
\hline $\begin{array}{c}\text { PoodLL } \\
\text { Anywhere(Atto) }\end{array}$ & $\begin{array}{c}\text { Atto Editor } \\
\text { Plugin }\end{array}$ & $\begin{array}{l}\text { Забезпечує іконку для кожного аудіо запису і малюнка на } \\
\text { дошці в Аtto html еditor. Студенти і вчителі можуть } \\
\text { ефективно використовувати PоодL в будь-якому місці }\end{array}$ \\
\hline
\end{tabular}

Додаток Listening Landscape для системи Moodle. Цей додаток діяльності дозволяє в системі Moodle створювати вправи з аудіювання для вивчення іноземних мов [6]. Вправи в основному складається 3 двох файлів: відеофайл і файл субтитрів (рис. 3).

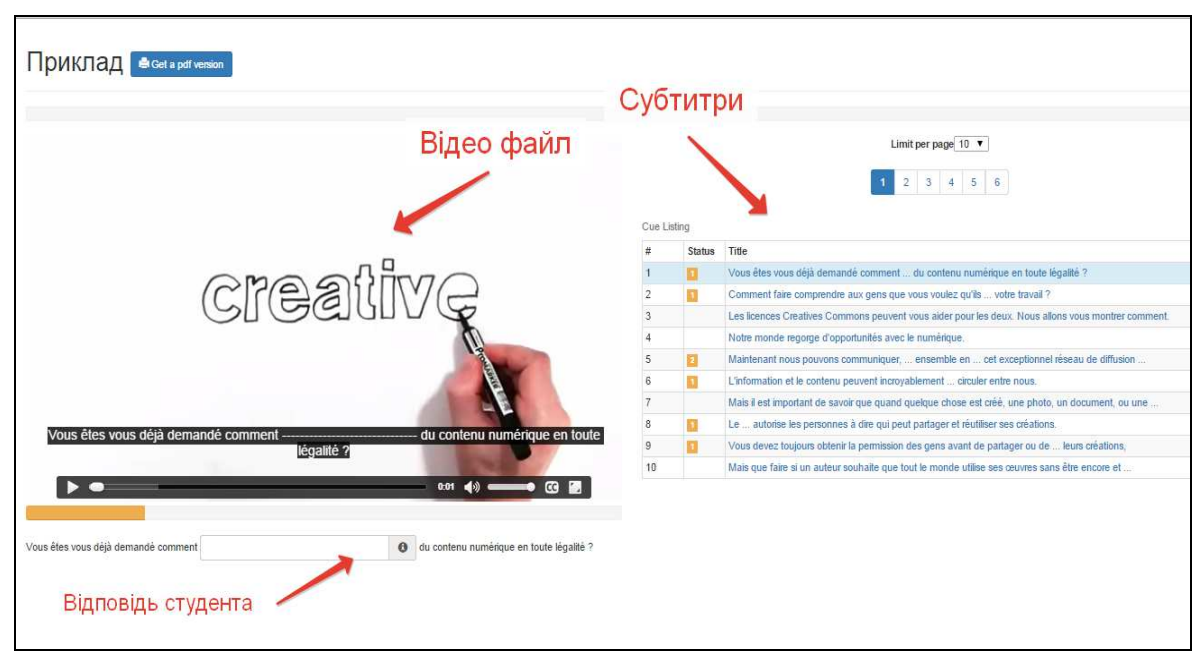

Puc. 3. Вікно додаткуListening Landscape

Файл відео підтримує формати: ogv, webm, mp4. Вони потрібні для коректної роботи з браузерами, тому що деякі з них працюють тільки з одним із вище вказаних форматів відеофайлу.

Файл субтитрів підтримує формати: srt i vtt, використовуючи utf-8 кодування.

Під час створення файлу субтитрів викладач вписує текст між квадратними або фігурними дужками і саме цей текст студент повинен вгадати і записати у відповідь. Якщо текст записаний між квадратними дужками, то студент має змогу взяти підказку і подивитися правильну відповідь. Текст, записаний між фігурними дужками, підказок не має.

Також студент має змогу завантажити PDF версію вправи.

Додаток YоuTube Anywhere для системи Moodle. Цей додаток дозволяє викладачам і студентам у будь-якому текстовому редакторі Moodle записувати відеофйли з веб-камери і мобільних пристроїв та завантажувати на YouTube (рис. 4, 5) [9].

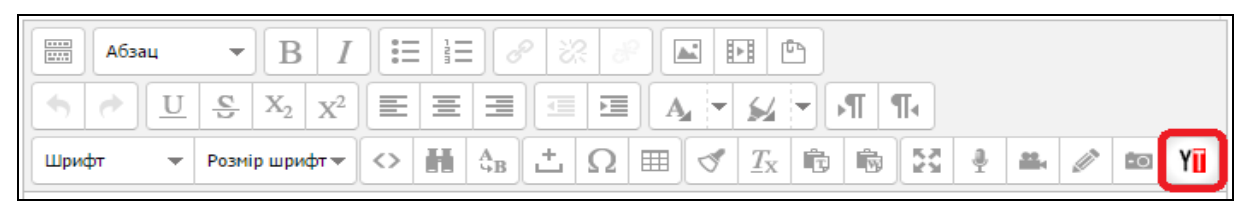

Puc. 4. Додаток ҮоиТиbe Anywhere в текстовому редакторі Moodle 


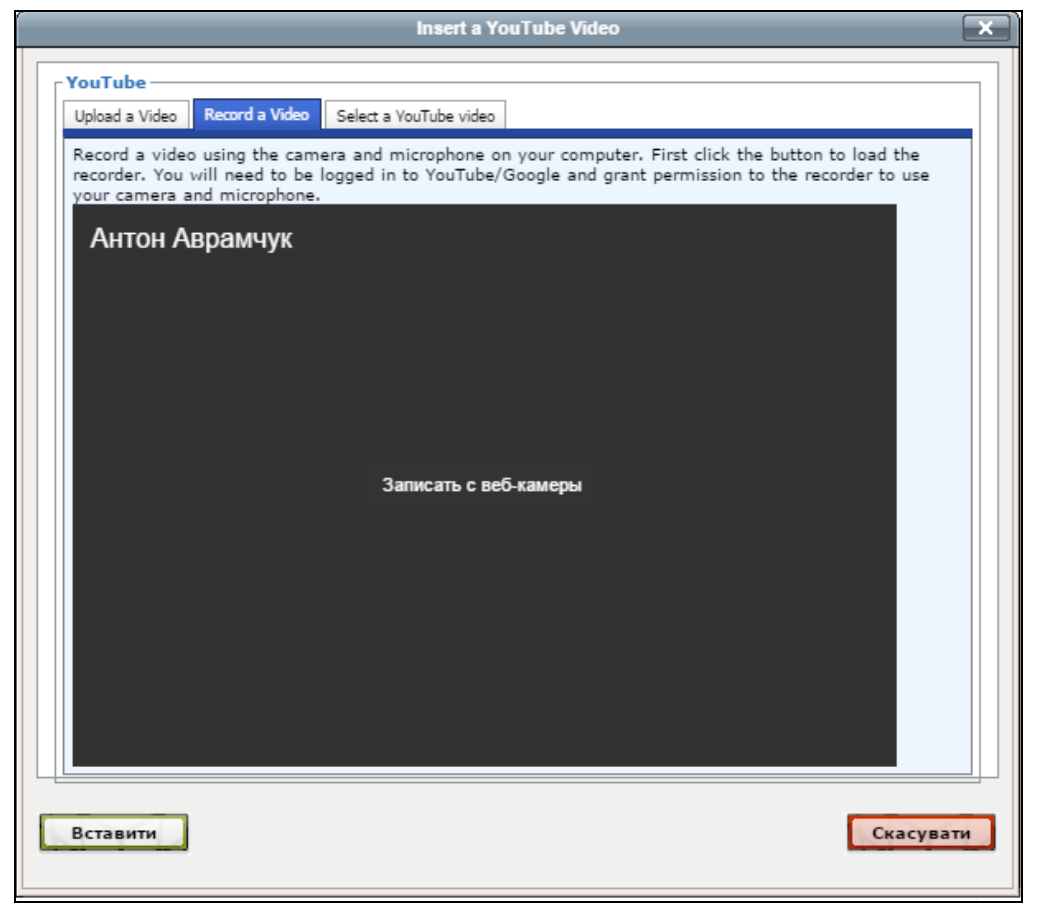

Pис. 5. Запис відео за допомогою додатку YоиTube Anywhere

Додаток NanoGong для системи Moodle. NanoGong забезпечує дуже просту i прозору голосову підтримку в системі Moodle [8]. NanoGong може бути використаний для запису, відтворення та збереження голосу на веб-сторінці. NanoGong використовується в HTML текстовому редакторі, і надає можливість надзвичайно легко додати звукові об'єкти в межах текстового редактора. Це означає, що ви можете створити збагачений звуком вміст будь де в Moodle (рис. 6, 7).

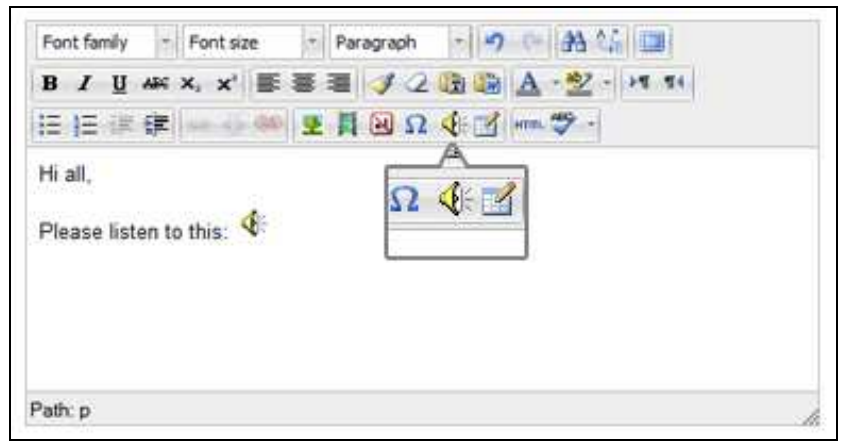

Рис. 6. Створення звукового об'єкта в редакторі НTML

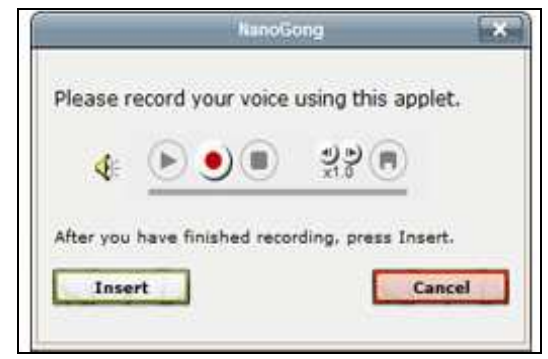

Pис. 7. Відкрите вікно додатку NaпоGong для запису звукового об'єкта 
Порівняння додатків для системи Moodle. Підсумкові дані для порівняння розглянутих додатків системи Moodle наведені в табл. 3.

\section{Порівняння додатків системи Moоdle}

\begin{tabular}{|c|c|c|c|c|c|c|c|c|}
\hline $\begin{array}{c}\text { Назва } \\
\text { додатку }\end{array}$ & 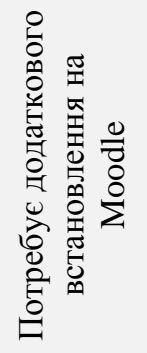 & 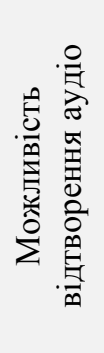 & 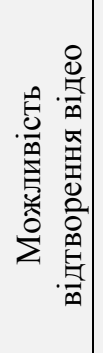 & 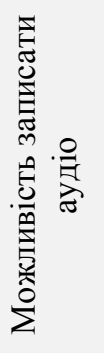 & 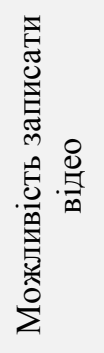 & 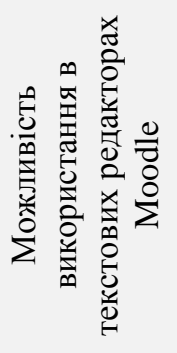 & 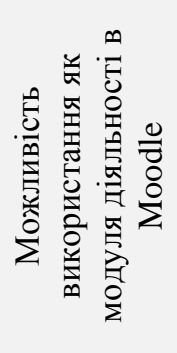 & 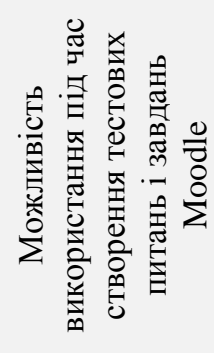 \\
\hline $\begin{array}{l}\text { Rich } \\
\text { Media }\end{array}$ & + & + & + & - & - & - & + & - \\
\hline PoodLL & + & + & + & + & + & + & - & + \\
\hline $\begin{array}{l}\text { Listening } \\
\text { Landscape }\end{array}$ & + & + & + & - & - & - & + & - \\
\hline $\begin{array}{l}\text { YouTube } \\
\text { Anywhere }\end{array}$ & + & + & + & + & + & + & - & + \\
\hline NanoGong & + & + & - & + & - & + & - & + \\
\hline
\end{tabular}

Задля вибору найкращого серед п'яти розглянутих автором додатків системи Moodle для проектування мультимедійних електронних освітніх ресурсів 3 мовних дисциплін, застосуємо метод аналізу ієрархій [5]. Цей метод передбачає поетапне виконання розрахунків:

$\checkmark$ формування групи експертів;

$\checkmark$ розроблення системи критеріїв, за якими буде виконуватися аналіз.

Група експертів складається 34 чоловік, включаючи автора. Це незалежні кваліфіковані фахівці, що мають досвід роботи в даній сфері діяльності. Вибір найкращого додатку будемо виконувати за поданими нижче критеріями.

1. Ефективність додатку (розуміється, який саме додаток системи Moodle може бути корисним i результативним для проектування мультимедійних електронних освітніх ресурсів з мовних дисциплін, щ, у свою чергу, буде сприяти кращому вивченню мовних дисциплін студентами).

2. Функціональність додатку (розуміється, які саме функціональні можливості той чи інший додаток системи Moodle має для проектування мультимедійних електронних освітніх ресурсів з мовних дисциплін).

3. Простота використання (розуміється, який саме додаток системи Moodle може бути простий у використанні під час проектування мультимедійних електронних освітніх ресурсів з мовних дисциплін).

На рис. 8 показана структура ієрархічної моделі вибору, критерії та альтернативи. 


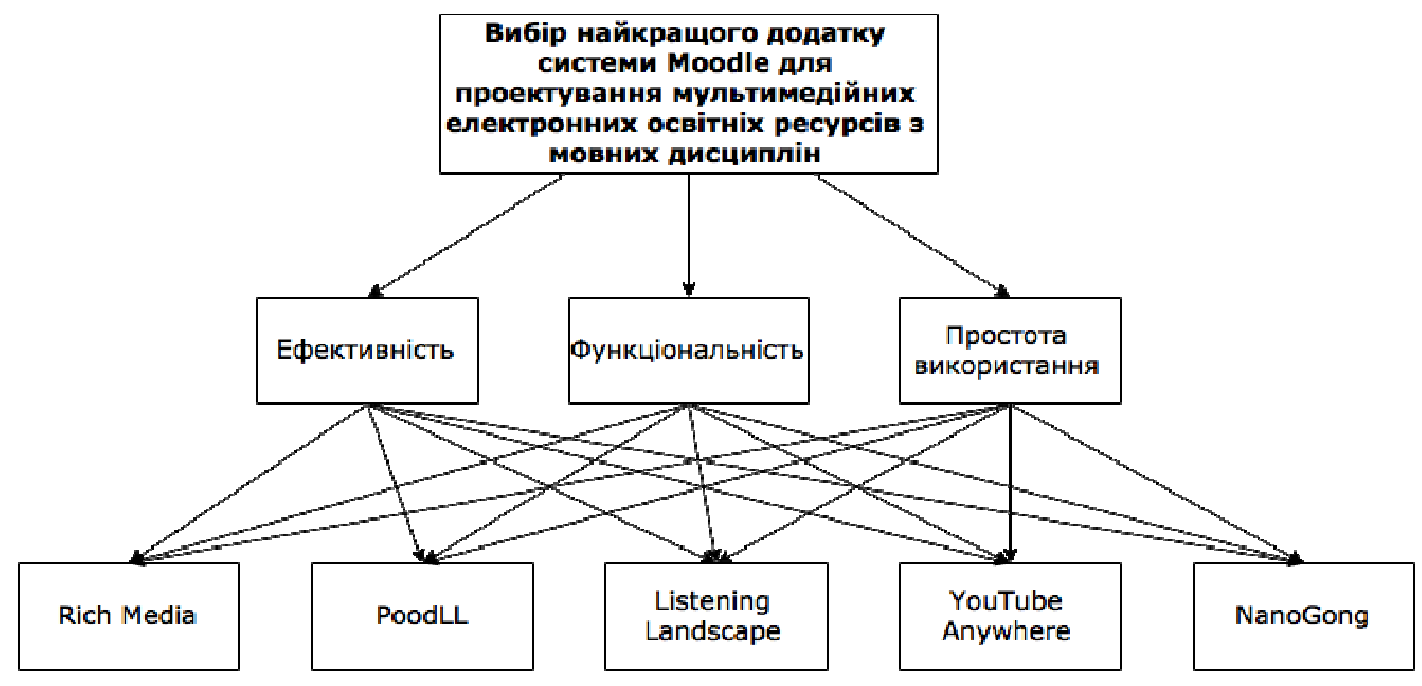

Рис. 8. Структура ієрархічної моделі вибору

У табл. 4-7 наведені вагові коефіцієнти критеріїв, які надає їм автор з групою експертів.

Таблиияя 4

\section{Порівняння критеріїв (Експерт 1)}

\begin{tabular}{|c|c|c|c|c|}
\hline Показники & Ефективність & Функціональність & $\begin{array}{c}\text { Простота } \\
\text { використання }\end{array}$ & $\begin{array}{r}\text { Локальні } \\
\text { пріоритети }\end{array}$ \\
\hline Ефективність & 1 & 3 & 7 & 0,669 \\
\hline Функціональність & $1 / 3$ & 1 & 3 & 0,243 \\
\hline $\begin{array}{c}\text { Простота } \\
\text { використання }\end{array}$ & $1 / 7$ & $1 / 3$ & 1 & 0,088 \\
\hline \multicolumn{5}{|c|}{$\mu_{\max }=3.007, \mathrm{IV}=0.004 ; \mathrm{BV}=0.006$} \\
\hline
\end{tabular}

Таблиия 5

\section{Порівняння критеріїв (Експерт 2)}

\begin{tabular}{|c|c|c|c|c|}
\hline Показники & Ефективність & Функціональність & $\begin{array}{c}\text { Простота } \\
\text { використання }\end{array}$ & $\begin{array}{c}\text { Локальні } \\
\text { пріоритети }\end{array}$ \\
\hline Ефективність & 1 & $1 / 3$ & 3 & 0,281 \\
\hline Функціональність & 3 & 1 & 3 & 0,584 \\
\hline $\begin{array}{c}\text { Простота } \\
\text { використання }\end{array}$ & $1 / 3$ & $1 / 3$ & 1 & 0,135 \\
\hline \multicolumn{5}{|c|}{$\mu_{\max }=3.136: \mathrm{IV}=0.068: \mathrm{EV}=0,117$} \\
\end{tabular}


Таблиия 6

\section{Порівняння критеріїв (Експерт 3)}

\begin{tabular}{|c|c|c|c|c|}
\hline Показники & Ефективність & Функціональність & $\begin{array}{c}\text { Простота } \\
\text { використання }\end{array}$ & $\begin{array}{c}\text { Локальні } \\
\text { пріоритети }\end{array}$ \\
\hline Ефективність & 1 & 3 & 7 & 0,694 \\
\hline Функціональність & $1 / 3$ & 1 & 1 & 0,174 \\
\hline $\begin{array}{c}\text { Простота } \\
\text { використання }\end{array}$ & $1 / 7$ & 1 & 1 & 0,132 \\
\hline \multicolumn{5}{|l}{$=3.080: \mathrm{IV}=0.040 ; \mathrm{BV}=0.069$} \\
\hline
\end{tabular}

\section{Порівняння критеріїв (Експерт 4)}

\begin{tabular}{|c|c|c|c|c|}
\hline Показники & Ефективність & Функціональність & $\begin{array}{c}\text { Простота } \\
\text { використання }\end{array}$ & $\begin{array}{c}\text { Локальні } \\
\text { пріоритети }\end{array}$ \\
\hline Ефективність & 1 & 5 & 3 & 0,602 \\
\hline Функціональність & $1 / 5$ & 1 & $1 / 7$ & 0,075 \\
\hline $\begin{array}{c}\text { Простота } \\
\text { використання }\end{array}$ & $1 / 3$ & 7 & 1 & 0,324 \\
\hline \multicolumn{5}{|c|}{$\mu_{\max }=3,233 ; \mathrm{JV}=0,117 ; \mathrm{\Xi V}=0,20$} \\
\end{tabular}

Максимальне власне значення обернено-симетричної матриці попарних порівнянь визначається за формулою:

$$
\mu_{\max }=\sum_{j=1}^{n} \bar{u}_{j}\left(\sum_{i=1}^{n} \bar{a}_{i j}\right)
$$

Оцінки відносної важливості елементів, що порівнюються, повинні бути узгоджені, тому визначимо індекс (IУ) і відношення (ВУ) узгодженості:

$$
\begin{gathered}
I Y=\frac{\mu_{\max }-n}{n-1} \\
B У=\frac{I Y}{I Y B}
\end{gathered}
$$


Величина відношення узгодженості (ВУ) не повинна перевищувати 10-20\%, інакше слід ще раз дослідити задачу і переглянути значення коефіцієнтів у матриці попарних порівнянь.

На основі наведеного вище аналізу програмних засобів їм можна дати такі оцінки за критеріями ефективність, функціональність, простота використання.

Результати опитувань усереднюються і формується колективна думка членів експертної групи (за формулою середньої арифметичної простої). Результати наведенні в табл. 8.

Таблиия 8

\section{Результати опитування експертної групи}

\begin{tabular}{|c|c|c|c|c|c|}
\hline Критерії Експерти & Експерт 1 & Експерт 2 & Експерт 3 & Експерт 4 & $\begin{array}{c}\text { Середнс } \\
\text { арифметичне } \\
\text { значення }\end{array}$ \\
\hline Ефективність & 0,669 & 0,281 & 0,694 & 0,602 & 0,56 \\
\hline Функціональність & 0,243 & 0,584 & 0,174 & 0,075 & 0,27 \\
\hline $\begin{array}{c}\text { Простота } \\
\text { використання }\end{array}$ & 0,088 & 0,135 & 0,132 & 0,324 & 0,17 \\
\hline
\end{tabular}

Далі група експертів порівнює альтернативи за критеріями, де після кожного порівняння усереднює і формує колективну думку членів експертної групи.

Результати порівняння альтернатив за критеріями представлені в табл. 9-23.

Порівняння альтернатив за критерісм Ефективність (Експерт 1)

\begin{tabular}{|c|c|c|c|c|c|c|}
\hline Альтернатива & $\begin{array}{c}\text { Rich } \\
\text { Media }\end{array}$ & PoodLL & $\begin{array}{c}\text { Listening } \\
\text { Landscape }\end{array}$ & $\begin{array}{c}\text { YouTube } \\
\text { Anywhere }\end{array}$ & NanoGong & $\begin{array}{c}\text { Локальні } \\
\text { пріоритети } \\
\boldsymbol{\nu}_{i}\end{array}$ \\
\hline Rich Media & 1 & $1 / 3$ & $1 / 3$ & 3 & 7 & 0,17 \\
\hline PoodLL & 3 & 1 & 3 & 3 & 7 & 0,42 \\
\hline $\begin{array}{c}\text { Listening } \\
\text { Landscape }\end{array}$ & 3 & $1 / 3$ & 1 & 3 & 7 & 0,27 \\
\hline $\begin{array}{c}\text { YouTube } \\
\text { Anywhere }\end{array}$ & $1 / 3$ & $1 / 3$ & $1 / 3$ & 1 & 3 & 0,1 \\
\hline NanoGong & $1 / 7$ & $1 / 7$ & $1 / 7$ & $1 / 3$ & 1 & 0,04 \\
\hline \multicolumn{7}{c}{} \\
\end{tabular}


Порівняння альтернатив за критерієм Ефективність (Експерт 2)

\begin{tabular}{|c|c|c|c|c|c|c|}
\hline Альтернатива & $\begin{array}{c}\text { Rich } \\
\text { Media }\end{array}$ & PoodLL & $\begin{array}{c}\text { Listening } \\
\text { Landscape }\end{array}$ & $\begin{array}{c}\text { YouTube } \\
\text { Anywhere }\end{array}$ & NanoGong & $\begin{array}{c}\text { Локальні } \\
\text { пріоитети } \\
\boldsymbol{v}_{i}\end{array}$ \\
\hline Rich Media & 1 & $1 / 7$ & $1 / 3$ & $1 / 3$ & 7 & 0,1 \\
\hline PoodLL & 7 & 1 & $1 / 3$ & 3 & 7 & 0,33 \\
\hline $\begin{array}{c}\text { Listening } \\
\text { Landscape }\end{array}$ & 3 & 3 & 1 & 1 & 7 & 0,35 \\
\hline $\begin{array}{c}\text { YouTube } \\
\text { Anywhere }\end{array}$ & 3 & $1 / 3$ & 1 & 1 & 3 & 0,19 \\
\hline NanoGong & $1 / 7$ & $1 / 7$ & $1 / 7$ & $1 / 3$ & 1 & 0,04 \\
\hline \multicolumn{7}{|l}{} \\
\hline
\end{tabular}

Таблиия 11

Порівняння альтернатив за критерісм Ефективність (Експерт 3)

\begin{tabular}{|c|c|c|c|c|c|c|}
\hline Альтернатива & $\begin{array}{l}\text { Rich } \\
\text { Media }\end{array}$ & PoodLL & $\begin{array}{l}\text { Listening } \\
\text { Landscape }\end{array}$ & $\begin{array}{l}\text { YouTube } \\
\text { Anywhere }\end{array}$ & NanoGong & $\begin{array}{c}\text { Локальні } \\
\text { пріоритети } \\
v_{t} \\
\end{array}$ \\
\hline Rich Media & 1 & 3 & 1 & 3 & 7 & 0,36 \\
\hline PoodLL & $1 / 3$ & 1 & 3 & 3 & 9 & 0,30 \\
\hline $\begin{array}{l}\text { Listening } \\
\text { Landscape }\end{array}$ & 1 & $1 / 3$ & 1 & $1 / 3$ & 7 & 0,15 \\
\hline $\begin{array}{l}\text { YouTube } \\
\text { Anywhere }\end{array}$ & $1 / 3$ & $1 / 3$ & 3 & 1 & 3 & 0,16 \\
\hline NanoGong & $1 / 7$ & $1 / 9$ & $1 / 7$ & $1 / 3$ & 1 & 0,04 \\
\hline
\end{tabular}

Табличя 12

Порівняння альтернатив за критерісм Ефективність (Експерт 4)

\begin{tabular}{|c|c|c|c|c|c|c|}
\hline Альтернатива & $\begin{array}{l}\text { Rich } \\
\text { Media }\end{array}$ & PoodLL & $\begin{array}{c}\text { Listening } \\
\text { Landscape }\end{array}$ & $\begin{array}{l}\text { YouTube } \\
\text { Anywhere }\end{array}$ & NanoGong & $\begin{array}{c}\text { Локальні } \\
\text { пріоритети } \\
v_{i} \\
\end{array}$ \\
\hline Rich Media & 1 & $1 / 3$ & $1 / 3$ & 3 & 7 & 0,17 \\
\hline PoodLL & 3 & 1 & 3 & 3 & 7 & 0,42 \\
\hline $\begin{array}{l}\text { Listening } \\
\text { Landscape }\end{array}$ & 3 & $1 / 3$ & 1 & 3 & 7 & 0,27 \\
\hline $\begin{array}{l}\text { YouTube } \\
\text { Anywhere }\end{array}$ & $1 / 3$ & $1 / 3$ & $1 / 3$ & 1 & 3 & 0,1 \\
\hline NanoGong & $1 / 7$ & $1 / 7$ & $1 / 7$ & $1 / 3$ & 1 & 0,04 \\
\hline
\end{tabular}


Таблиия 13

Результати опитування експертної групи за критерієм Ефективність

\begin{tabular}{|c|c|c|c|c|c|}
\hline Альтернатива & & & & $\begin{array}{c}\text { Середнс } \\
\text { арифметичне } \\
\text { значення }\end{array}$ \\
\hline Rich Media & Eксnерm 1 & Eксnерm 2 & Eксnерm 3 & Eксnерm 4 & \\
\hline PoodLL & 0,17 & 0,1 & 0,36 & 0,17 & $\mathbf{0 , 2}$ \\
\hline Listening Landscape & 0,42 & 0,33 & 0,30 & 0,42 & $\mathbf{0 , 3 6}$ \\
\hline YouTube Anywhere & 0,1 & 0,35 & 0,15 & 0,27 & $\mathbf{0 , 2 6}$ \\
\hline NanoGong & 0,04 & 0,19 & 0,16 & 0,1 & $\mathbf{0 , 1 4}$ \\
\hline
\end{tabular}

Таблиия 14

Порівняння альтернатив за критерієм Функціональність (Експерт 1)

\begin{tabular}{|c|c|c|c|c|c|c|}
\hline Альтернатива & $\begin{array}{l}\text { Rich } \\
\text { Media }\end{array}$ & PoodLL & $\begin{array}{l}\text { Listening } \\
\text { Landscape }\end{array}$ & $\begin{array}{l}\text { YouTube } \\
\text { Anywhere }\end{array}$ & NanoGong & $\begin{array}{c}\text { Локальні } \\
\text { пріоритети } \\
v_{i} \\
\end{array}$ \\
\hline Rich Media & 1 & $1 / 7$ & $1 / 3$ & 3 & 7 & 0,13 \\
\hline PoodLL & 7 & 1 & 7 & 7 & 7 & 0,61 \\
\hline $\begin{array}{l}\text { Listening } \\
\text { Landscape }\end{array}$ & 3 & $1 / 7$ & 1 & $1 / 3$ & 3 & 0,11 \\
\hline $\begin{array}{l}\text { YouTube } \\
\text { Anywhere }\end{array}$ & $1 / 3$ & $1 / 7$ & 3 & 1 & 7 & 0,13 \\
\hline NanoGong & $1 / 7$ & $1 / 7$ & $1 / 3$ & $1 / 7$ & 1 & 0,03 \\
\hline
\end{tabular}

Табличя 15

Порівняння альтернатив за критерісм Функціональність (Експерт 2)

\begin{tabular}{|c|c|c|c|c|c|c|}
\hline Альтернатива & $\begin{array}{l}\text { Rich } \\
\text { Media }\end{array}$ & PoodLL & $\begin{array}{l}\text { Listening } \\
\text { Landscape }\end{array}$ & $\begin{array}{l}\text { YouTube } \\
\text { Anywhere }\end{array}$ & NanoGong & $\begin{array}{c}\text { Локальні } \\
\text { пріоритети } \\
v_{i} \\
\end{array}$ \\
\hline Rich Media & 1 & $1 / 9$ & 1 & 3 & 7 & 0,17 \\
\hline PoodLL & 9 & 1 & 3 & 3 & 7 & 0,50 \\
\hline $\begin{array}{l}\text { Listening } \\
\text { Landscape }\end{array}$ & 1 & $1 / 3$ & 1 & 1 & 7 & 0,17 \\
\hline $\begin{array}{l}\text { YouTube } \\
\text { Anywhere }\end{array}$ & $1 / 3$ & $1 / 3$ & 1 & 1 & 5 & 0,13 \\
\hline NanoGong & $1 / 7$ & $1 / 7$ & $1 / 7$ & $1 / 5$ & 1 & 0,03 \\
\hline
\end{tabular}


Табличя 16

\section{Порівняння альтернатив за критерієм Функціональність (Експерт 3)}

\begin{tabular}{|c|c|c|c|c|c|c|}
\hline Альтернатива & $\begin{array}{l}\text { Rich } \\
\text { Media }\end{array}$ & PoodLL & $\begin{array}{l}\text { Listening } \\
\text { Landscape }\end{array}$ & $\begin{array}{l}\text { YouTube } \\
\text { Anywhere }\end{array}$ & NanoGong & $\begin{array}{c}\text { Локальні } \\
\text { пріоритети } \\
v_{i} \\
\end{array}$ \\
\hline Rich Media & 1 & $1 / 5$ & 1 & 3 & 5 & 0,17 \\
\hline PoodLL & 5 & 1 & 3 & 7 & 7 & 0,51 \\
\hline $\begin{array}{l}\text { Listening } \\
\text { Landscape }\end{array}$ & 1 & $1 / 3$ & 1 & 3 & 7 & 0,20 \\
\hline $\begin{array}{l}\text { YouTube } \\
\text { Anywhere }\end{array}$ & $1 / 3$ & $1 / 7$ & $1 / 3$ & 1 & 5 & 0,08 \\
\hline NanoGong & $1 / 5$ & $1 / 7$ & $1 / 7$ & $1 / 5$ & 1 & 0,03 \\
\hline
\end{tabular}

Таблиия 17

Порівняння альтернатив за критерієм Функціональність (Експерт 4)

\begin{tabular}{|c|c|c|c|c|c|c|}
\hline Альтернатива & $\begin{array}{c}\text { Rich } \\
\text { Media }\end{array}$ & PoodLL & $\begin{array}{c}\text { Listening } \\
\text { Landscape }\end{array}$ & $\begin{array}{c}\text { YouTube } \\
\text { Anywhere }\end{array}$ & NanoGong & $\begin{array}{c}\text { Локальні } \\
\text { проритети } \\
v_{i}\end{array}$ \\
\hline Rich Media & 1 & $1 / 7$ & $1 / 3$ & $1 / 3$ & 3 & 0,08 \\
\hline PoodLL & 7 & 1 & 3 & 3 & 5 & 0,47 \\
\hline $\begin{array}{c}\text { Listening } \\
\text { Landscape }\end{array}$ & 3 & $1 / 3$ & 1 & $1 / 3$ & 3 & 0,15 \\
\hline $\begin{array}{c}\text { YouTube } \\
\text { Anywhere }\end{array}$ & 3 & $1 / 3$ & 3 & 1 & 5 & 0,25 \\
\hline NanoGong & $1 / 3$ & $1 / 5$ & $1 / 3$ & $1 / 5$ & 1 & 0,05 \\
\hline \multicolumn{7}{|l}{$\mu_{\max }=5,31 ; \mathrm{NV}=0,079 ; \mathrm{BV}=0,063$} \\
\hline
\end{tabular}

Табличя 18

Результати опитування експертної групи за критерісм Функціональність

\begin{tabular}{|c|c|c|c|c|c|}
\hline Альтернатива Експерти & Експерт 1 & Експерт 2 & Експерт 3 & Експерт 4 & $\begin{array}{c}\text { Середнс } \\
\text { арифметичне } \\
\text { значення }\end{array}$ \\
\hline Rich Media & 0,13 & 0,17 & 0,17 & 0,08 & 0,13 \\
\hline PoodLL & 0,61 & 0,50 & 0,51 & 0,47 & $\mathbf{0 , 5 2}$ \\
\hline Listening Landscape & 0,11 & 0,17 & 0,20 & 0,15 & 0,16 \\
\hline YouTube Anywhere & 0,13 & 0,13 & 0,08 & 0,25 & 0,15 \\
\hline NanoGong & 0,03 & 0,03 & 0,03 & 0,05 & 0,035 \\
\hline
\end{tabular}


Таблиия 19

\section{Порівняння альтернатив за критерієм Простота використання (Експерт 1)}

\begin{tabular}{|c|c|c|c|c|c|c|}
\hline Альтернатива & $\begin{array}{c}\text { Rich } \\
\text { Media }\end{array}$ & PoodLL & $\begin{array}{c}\text { Listening } \\
\text { Landscape }\end{array}$ & $\begin{array}{c}\text { YouTube } \\
\text { Anywhere }\end{array}$ & NanoGong & $\begin{array}{c}\text { Локальні } \\
\text { притети } \\
v_{i}\end{array}$ \\
\hline Rich Media & 1 & $1 / 7$ & $1 / 3$ & $1 / 7$ & $1 / 3$ & 0,04 \\
\hline PoodLL & 7 & 1 & 7 & 1 & 1 & 0,32 \\
\hline $\begin{array}{c}\text { Listening } \\
\text { Landscape }\end{array}$ & 3 & $1 / 7$ & 1 & $1 / 7$ & $1 / 7$ & 0,06 \\
\hline $\begin{array}{c}\text { YouTube } \\
\text { Anywhere }\end{array}$ & 7 & 1 & 7 & 1 & 1 & 0,32 \\
\hline NanoGong & 3 & 1 & 7 & 1 & 1 & 0,27 \\
\hline \multicolumn{7}{|c|}{} \\
\hline
\end{tabular}

Таблиия 20

\section{Порівняння альтернатив за критерієм Простота використання (Експерт 2)}

\begin{tabular}{|c|c|c|c|c|c|c|}
\hline Альтернатива & $\begin{array}{c}\text { Rich } \\
\text { Media }\end{array}$ & PoodLL & $\begin{array}{c}\text { Listening } \\
\text { Landscape }\end{array}$ & $\begin{array}{c}\text { YouTube } \\
\text { Anywhere }\end{array}$ & NanoGong & $\begin{array}{c}\text { Локальні } \\
\text { пріритети } \\
v_{i}\end{array}$ \\
\hline Rich Media & 1 & $1 / 5$ & 1 & $1 / 7$ & $1 / 3$ & 0,06 \\
\hline PoodLL & 5 & 1 & 7 & 1 & 1 & 0,33 \\
\hline $\begin{array}{c}\text { Listening } \\
\text { Landscape }\end{array}$ & 1 & $1 / 7$ & 1 & $1 / 3$ & $1 / 3$ & 0,07 \\
\hline $\begin{array}{c}\text { YouTube } \\
\text { Anywhere }\end{array}$ & 7 & 1 & 3 & 1 & 1 & 0,29 \\
\hline NanoGong & 3 & 1 & 3 & 1 & 1 & 0,25 \\
\hline \multicolumn{7}{|c|}{$\mu_{\max }=5,14 ; \mathrm{IV}=0,034 ; \mathrm{BV}=0,03$} \\
\hline
\end{tabular}

Табличя 21

\section{Порівняння альтернатив за критерієм Простота використання (Експерт 3)}

\begin{tabular}{|c|c|c|c|c|c|c|}
\hline Альтернатива & $\begin{array}{c}\text { Rich } \\
\text { Media }\end{array}$ & PoodLL & $\begin{array}{c}\text { Listening } \\
\text { Landscape }\end{array}$ & $\begin{array}{c}\text { YouTube } \\
\text { Anywhere }\end{array}$ & NanoGong & $\begin{array}{c}\text { Локальні } \\
\text { проритети } \\
v_{i}\end{array}$ \\
\hline Rich Media & 1 & $1 / 9$ & 1 & $1 / 7$ & $1 / 5$ & 0,04 \\
\hline PoodLL & 9 & 1 & 7 & 1 & 3 & 0,40 \\
\hline $\begin{array}{c}\text { Listening } \\
\text { Landscape }\end{array}$ & 1 & $1 / 7$ & 1 & $1 / 5$ & $1 / 5$ & 0,05 \\
\hline $\begin{array}{c}\text { YouTube } \\
\text { Anywhere }\end{array}$ & 7 & 1 & 5 & 1 & 1 & 0,29 \\
\hline NanoGong & 5 & $1 / 3$ & 5 & 1 & 1 & 0,22 \\
\hline \multicolumn{7}{|l}{} \\
\hline
\end{tabular}


Табличя 22

\section{Порівняння альтернатив за критерієм Простота використання (Експерт 4)}

\begin{tabular}{|c|c|c|c|c|c|c|}
\hline Альтернатива & $\begin{array}{c}\text { Rich } \\
\text { Media }\end{array}$ & PoodLL & $\begin{array}{c}\text { Listening } \\
\text { Landscape }\end{array}$ & $\begin{array}{c}\text { YouTube } \\
\text { Anywhere }\end{array}$ & NanoGong & $\begin{array}{c}\text { Локальні } \\
\text { пріоритети } \\
v_{i}\end{array}$ \\
\hline Rich Media & 1 & $1 / 7$ & 3 & $1 / 7$ & $1 / 3$ & 0,07 \\
\hline PoodLL & 7 & 1 & 7 & 1 & 1 & 0,32 \\
\hline $\begin{array}{c}\text { Listening } \\
\text { Landscape }\end{array}$ & $1 / 3$ & $1 / 7$ & 1 & $1 / 5$ & $1 / 7$ & 0,04 \\
\hline $\begin{array}{c}\text { YouTube } \\
\text { Anywhere }\end{array}$ & 7 & 1 & 5 & 1 & 1 & 0,30 \\
\hline NanoGong & 3 & 1 & 7 & 1 & 1 & 0,27 \\
\hline & \multicolumn{7}{|l}{$\mu_{\max }=5,15 ; \mathrm{N}=0.038 ; \mathrm{BV}=0.03$} & & \\
\hline
\end{tabular}

Таблиця 23

Результати опитування експертної групи за критерісм Простота використання

\begin{tabular}{|c|c|c|c|c|c|}
\hline Альтернатива Експерти & Експерт 1 & Експерт 2 & Експерт 3 & Експерт 4 & $\begin{array}{c}\text { Середнс } \\
\text { арифметичн } \\
\text { е значення }\end{array}$ \\
\hline Rich Media & 0,04 & 0,06 & 0,04 & 0,07 & 0,052 \\
\hline PoodLL & 0,32 & 0,33 & 0,40 & 0,32 & 0,34 \\
\hline Listening Landscape & 0,06 & 0,07 & 0,05 & 0,04 & 0,22 \\
\hline YouTube Anywhere & 0,32 & 0,29 & 0,29 & 0,30 & 0,3 \\
\hline NanoGong & 0,27 & 0,25 & 0,22 & 0,27 & 0,25 \\
\hline
\end{tabular}

На основі таблиць $8,13,18,23$ розраховуємо глобальні пріоритети.

Глобальні пріоритети W визначаються як суми добутків нормалізованих векторів локальних пріоритетів альтернатив і нормалізованих векторів локальних пріоритетів відповідних їм критеріїв.

Звідси розраховуємо значення глобальних пріоритетів:

$$
\begin{aligned}
& W_{\text {Rich Media }}=v_{1} u_{1}+v_{6} u_{2}+v_{11} u_{3} \\
& W_{\text {poodul }}=v_{2} u_{1}+v_{7} u_{2}+v_{12} u_{3} \\
& W_{\text {Listeming Landgcape }}=v_{3} u_{1}+v_{8} u_{2}+v_{13} u_{3} \\
& W_{\text {YouTube Anywhere }}=v_{4} u_{1}+v_{9} u_{2}+v_{14} u_{3} \\
& W_{\text {NanoGong }}=v_{5} u_{1}+v_{10} u_{2}+v_{15} u_{3}
\end{aligned}
$$




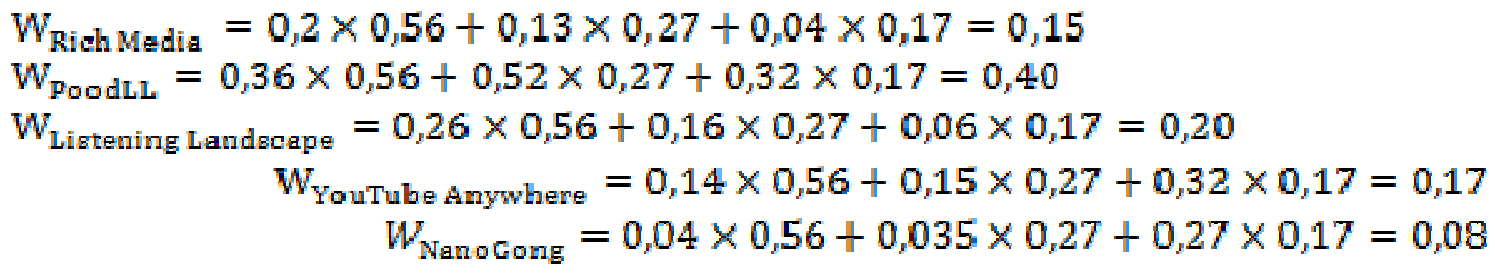

Табличя 24

Значення глобальних пріоритетів

\begin{tabular}{|c|c|c|c|c|}
\hline \multirow{2}{*}{$\begin{array}{c}\text { Критерій } \\
\text { Альтернатива }\end{array}$} & Ефективність & Функціональність & $\begin{array}{c}\text { Простота } \\
\text { використання }\end{array}$ & $\begin{array}{c}\text { Глобальний } \\
\text { пріоритет }\end{array}$ \\
\cline { 2 - 5 } & $\mathbf{0 , 5 6}$ & $\mathbf{0 , 2 7}$ & $\mathbf{0 , 1 7}$ & \\
\hline Rich Media & 0,2 & 0,13 & 0,04 & $\mathbf{0 , 1 5}$ \\
\hline PoodLL & 0,36 & 0,52 & 0,32 & $\mathbf{0 , 4 0}$ \\
\hline Listening Landscape & 0,26 & 0,16 & 0,06 & $\mathbf{0 , 2 0}$ \\
\hline YouTube Anywhere & 0,14 & 0,15 & 0,32 & $\mathbf{0 , 1 7}$ \\
\hline NanoGong & 0,04 & 0,035 & 0,27 & $\mathbf{0 , 0 8}$ \\
\hline
\end{tabular}

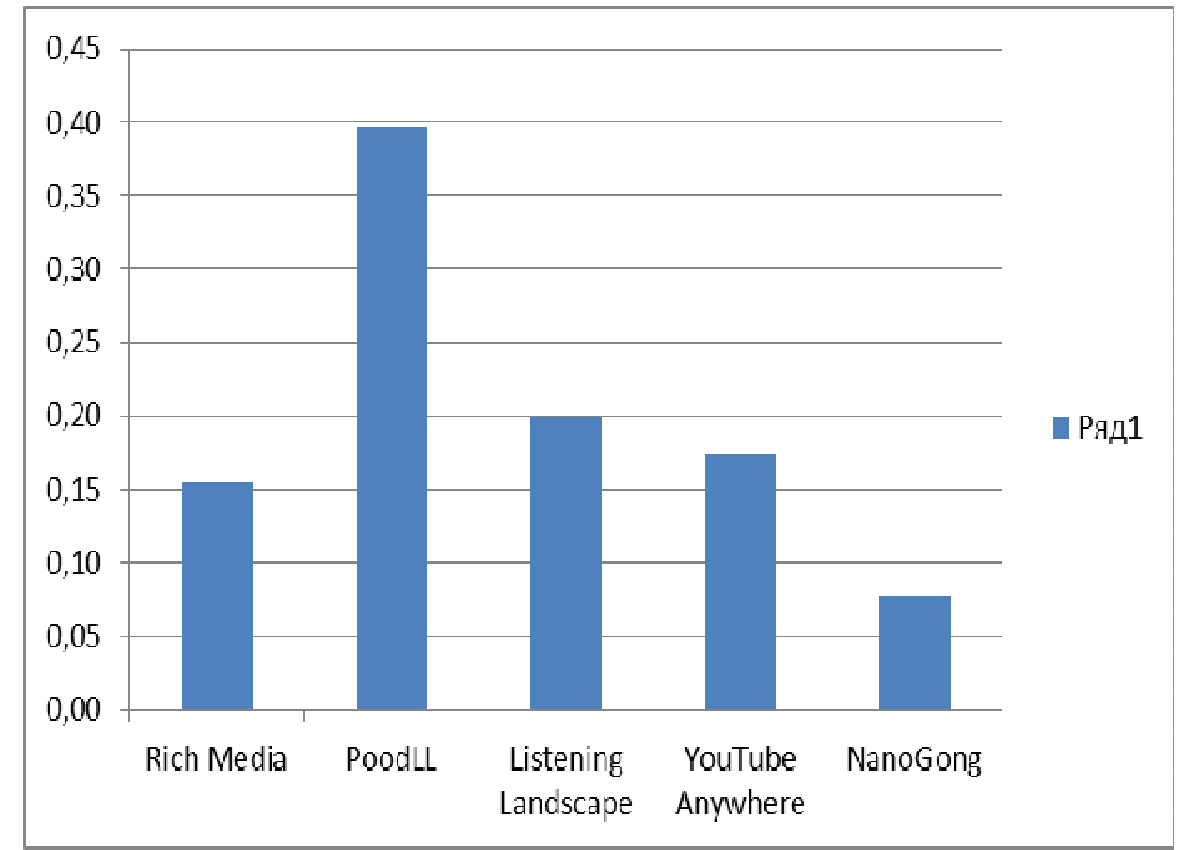

Рис. 9. Діаграма значень глобальних пріоритетів

\section{3. ВИСНОВКИ ТА ПЕРСПЕКТИВИ ПОДАЛЬШИХ ДОСЛІДЖЕНЬ}

Можливість використання додатків системи Moodle задля проектування i створення мультимедійних електронних освітніх ресурсів 3 мовних дисциплін $\epsilon$ актуальною проблемою i потребує подальших досліджень. Такі мультимедійні електронні освітні ресурси можуть значно спростити процес навчання студентів, 
зробити його більш продуктивним, ефективним, цікавим та підвищити інтерес до вивчення самих мовних дисциплін.

Наведений у статті огляд i порівняльний аналіз додатків системи Moodle допоможе викладачам з мовних дисциплін ближче ознайомитися з ними, зрозуміти, які функціональні можливості кожен додаток має і який є ефективнішим і простим у використанні.

У процесі дослідження за оцінками і ваговими коефіцієнтами критеріїв, що надає автор з групою експертів, найкращим додатком системи Moodle для проектування мультимедійних електронних освітніх ресурсів 3 мовних дисциплін серед п'яти розглянутих виявився PoodLL, який має найбільше значення глобального пріоритету, що дорівнює $0,40$.

Перспективи подальших досліджень у цьому напрямку вбачаються:

$\checkmark$ у пошуку нових додатків системи Moodle та інших програмних засобів для проектування мультимедійних електронних освітніх ресурсів 3 мовних дисциплін на основі системи Moodle;

$\checkmark$ у розробленні методичних рекомендацій щодо проектування мультимедійних електронних освітніх ресурсів 3 мовних дисциплін на основі системи Moodle.

Також $\epsilon$ актуальною проблема підготовки викладачів з мовних дисциплін щодо проектування і використання мультимедійних електронних освітніх ресурсів, що, у свою чергу, буде у них розвивати інформаційно-комунікаційно-технологічну компетентність.

\section{СПИСОК ВИКОРИСТАНИХ ДЖЕРЕЛ}

1. Аврамчук А. М. Створення відео лекцій за допомогою модуля Rich Media [Електронний ресурс] / А. М. Аврамчук, О. А. Щербина. - 2013. - Режим доступу до ресурсу : http://2013.moodlemoot.in.ua/course/view.php?id=51.

2. Аврамчук А. М. Огляд мультимедійних додатків платформи Moodle [Електронний ресурс] / Антон Миколайович Аврамчук // ІІТЗН НАПН України, м.Київ, Україна.. - 2014. - Режим доступу до pecypcy : http://conf.iitlt.gov.ua/Images/Files/1_109_1417869026_file.docx.

3. Аврамчук А. М. Огляд плагіна PoodLL для вивчення іноземних мов в системі Moodle [Електронний ресурс] / Антон Миколайович Аврамчук. - 2015. - Режим доступу до ресурсу : http://2015.moodlemoot.in.ua/course/view.php?id=108.

4. Денисенко С. М. Психолого-педагогічні засади проектування мультимедійного контенту електронних освітніх ресурсів для вищого навчального закладу : автореф. дис. на здобуття наук. ступеня канд. пед. наук : спец. 13.00 .10 "Інформаційно-комунікаційні технології в освіті" / Денисенко С. М. - Київ, 2013- 20 с.

5. Стандарт SCORM и его применение [Електронний ресурс]. - Режим доступу до ресурсу : http://cccp.ifmo.ru/scorm/index.html.

6. Т. Саати. Принятие решений. Метод анализа иерархий. Пер. с англ. Р. Г. Вачнадзе. - М.: Радио и связь, 1993, - 278 с.

7. Hunt J. Poodll'ing [Електронний pecypc] / Justin Hunt. - 2013. - Режим доступу до ресурсу : https://www.youtube.com/watch?v=-qpfmoVYYeI.

8. Listening Landscape [Електронний pecypc]. https://moodle.org/plugins/view/mod_elang.

9. Moodle. [Електронний ресурс]. - Режим доступу до ресурсу : https://moodle.org/.

10. NanoGong. [Електронний ресурс]. - Режим доступу до ресурсу : http://gong.ust.hk/nanogong/.

11. YouTube Anywhere [Електронний pecypc]. https://moodle.org/plugins/view/tinymce_youtube. 


\title{
ОБЗОР ПРИЛОЖЕНИЙ СИСТЕМЫ МООDLЕ ДЛЯ ПРОЕКТИРОВАНИЯ МУЛЬТИМЕДИЙНЫХ ЭЛЕКТРОННЫХ ОБРАЗОВАТЕЛЬНЫХ РЕСУРСОВ ПО ЯЗЫКОВЫМ ДИСЦИПЛИНАМ
}

\author{
Аврамчук Антон Николаевич \\ аспирант \\ Институт информационных технологий и средств обучения НАПН Украины, г. Киев, Украина \\ avramchuk92@gmail.com
}

\begin{abstract}
Аннотация. На сегодня проблема проектирования мультимедийных электронных образовательных ресурсов по языковым дисциплинам в системе Moodle является очень актуальной. Эта система имеет много различных, мощных ресурсов, приложений, чтобы облегчить процесс обучения студентов по языковым дисциплинам. В этой статье приведен обзор и сравнительный анализ пяти приложений системы Moodle для проектирования мультимедийных электронных образовательных ресурсов по языковым дисциплинам. Рассмотрены их основные характеристики и функциональные возможности с целью выбора лучшего для изучения языковых дисциплин в системе Moodle. Приложения сравниваются группой экспертов по критериям: эффективность, функциональность и простота использования. Для сравнительного анализа приложений применяется метод анализа иерархий.

Ключевые слова: электронные образовательные ресурсы; проектирования мультимедийных электронных образовательных ресурсов; эффективность; функциональность; простота использования; Moodle; Rich Media; PoodLL; Listening Landscape; YouTube Anywhere; NanoGong.
\end{abstract}

\section{REVIEW OF MOODLE PLUGINS FOR DESIGNING MULTIMEDIA ELECTRONIC EDUCATIONAL RESOURCES FROM LANGUAGE DISCIPLINES}

\author{
Anton M. Avramchuk \\ PhD student \\ Institute of Information Technologies and Learning Tools of NAES of Ukraine, Kyiv, Ukraine \\ avramchuk92@gmail.com
}

\begin{abstract}
Today the problem of designing multimedia electronic educational resources from language disciplines in Moodle is very important. This system has a lot of different, powerful resources, plugins to facilitate the learning of students with language disciplines. This article presents an overview and comparative analysis of the five Moodle plugins for designing multimedia electronic educational resources from language disciplines. There have been considered their key features and functionality in order to choose the best for studying language disciplines in the Moodle. Plugins are compared by a group of experts according to the criteria: efficiency, functionality and easy use. For a comparative analysis of the plugins it is used the analytic hierarchy process.
\end{abstract}

Keywords: electronic educational resources; designing electronic educational multimedia resources; efficiency; functionality; easy use; Moodle; Rich Media; PoodLL; Listening Landscape; YouTube Anywhere; NanoGong.

\section{REFERENCES (TRANSLATED AND TRANSLITERATED)}

1. Avramchuk A. M. Create a video lecture by the module Rich Media [online] / A.M. Avramchuk, O.A Shcherbyna. - 2013. - Available from: http://2013.moodlemoot.in.ua/course/view.php?id=51. (in Ukrainian)

2. Avramchuk A. M. Overview of multimedia plugins for the platform Moodle [online] / A. M. Avramchuk // IITLT of the NAPS of Ukraine, Kiev, Ukraine . - 2014 . http://conf.iitlt.gov.ua/Images/Files/1_109_1417869026_file.docx (in Ukrainian). 
3. Avramchuk A. M. Overview of the plugin PoodLL for learning foreign languages in the system Moodle [online] / A. M. Avramchuk. - $2015 . \quad$ - Available from: http://2015.moodlemoot.in.ua/course/view.php?id=108 (in Ukrainian).

4. Denisenko S. M. Psycho-pedagogical principles of designing multimedia content of electronic educational resources for higher education institutions: Author. Thesis. on competition sciences. degree candidate. ped. Sciences specials. 13.00.10 "Information and Communication Technologies in Education" / Denisenko SM - Kyiv, 2013. - 20 p. (in Ukrainian).

5. The standard SCORM and its application [online]. - Available from : http://cccp.ifmo.ru/scorm/index.html (in Russian)

6. T. Saaty. Adoption decisions. Methods of hierarchy analysis. Translate from English. R.G.Vachnadze. M $\therefore$ Radio and Communications, 1993. - 278 p. (in Russian).

7. Hunt J. Poodlling [online]. / Justin Hunt. - 2013. - Available from : https://www.youtube.com/watch?v=-qpfmoVYYeI (in English).

8. Listening Landscape [online]. - Available from : https://moodle.org/plugins/view/mod_elang (in English).

9. Moodle. [online]. - Available from : https://moodle.org/ (in English).

10. NanoGong [online]. - Available from : http://gong.ust.hk/nanogong/ (in English).

11. YouTube Anywhere [online]. - Available from : https://moodle.org/plugins/view/tinymce_youtube (in English). 